\title{
Social Determinants of Health and Disease: The Role of Small-Scale Projects Illustrated by the Koster Health Project in Sweden and Ametra in Peru
}

\author{
Determinantes Sociais de Saúde e Doença: O Papel de Pequenos \\ Projetos em Saúde llustrado pelos Projetos Koster na Suécia e Ametra \\ no Peru
}

\author{
Maj-Lis Follér'
}

\section{FOLLER, M. Social Determinants of Health and Disease: The Role of Small-Scale Projects} Illustrated by the Koster Health Project in Sweden and Ametra in Peru. Cad. Saude Públ., Rio de Janeiro, 8 (3): 229-239, jul/set, 1992.

Two different health projects are evaluated in this paper. The Koster Health project taking place at the Koster Islands in Sweden and the Ametra project going on among the Shipibo-Conibo in Peru. Both projects focus more on the determinants of health than on sickness and more on the individual's subjective feeling of illness than on the biomedically "objectively" recognizable disease. "Mobilization" and "responsibility" for the individual's own health are central concepts in both projects. In the theoretical part of the paper a human ecological perspective is suggested to analyse the interaction between human health and environmental changes. The author emphasizes the importance of interdisciplinary research when evaluating how the external determinants from the natural and social environment affect human beings and health. The human ecological approach is seen as a complement to the biomedical research. Health and disease are two poles in a continum. In a pluralistic society we should struggle towards the pole of health.

Keywords: Human Ecology; Health; Mobilization; Koster Islands; Shipibo-Conibo Indians

\section{INTRODUCTION}

Every society has its own sicknesses reflecting the socio-economic conditions of the society itself. They reflect not only economic, social and hygienic circumstances, not only the individuals ${ }^{\circ}$ way of living or their environment, but deeper values, norms and cultural patterns. The concept of health requires a discussion of the relation between the individual and society and how the concept is created and changes through new practices and aims at both a microlevel and a macrolevel.

Sicknesses are born, they are used, consumed and die (Johannisson, 1990). That

\footnotetext{
'Section of Human Ecology, University of Göteborg Brogatan 4, S-41301 Göteborg, Sweden.
}

is to say that the pattern of disease differs in time and space. That socio-economic status influences health status is nothing new or unique to certain populations or geographical areas.

The individual does not passively accept the environmental changes and socio-cultural events taking place around him/her. I will illustrate this by two very different projects, the Koster Health Project in Sweden and the Ametra Project in Peru. Besides being involved in these projects personally, $I$ find them interesting in the sense that both focus more on the determinants of health than on sickness and more on illness, the individual's subjective feeling, than disease, the objectively recognizable phenomenon. A welldefined national health policy and an active regional and local health policy are necessary components of any measures to improve the 
individual health status in the society. In this paper I will mostly discuss health activities from the grass-roots level. I will show some findings that illustrate that the mobilization of the people's own responsibility for their health has been beneficial to the individual's heal th situation. Socioeconomic status vis-àvis health status may be explained by the Health Field concept as presented by Lalonde (1974) and Blum (1981, 1983).

This framework contains four determinants. They can be seen as components in a force field interacting between the human being and the environment and hereby influencing his/her well-being.

The determinants are:

- environmental factors;

- lifestyles or individual ways of life;

- genetic factors;

- the health care system.

It states that the health status of individuals is under the influence of the environment, lifestyle, human biology, and the medical care system. It has been estimated that $50 \%$ of our health status is determined by lifestyle, $20 \%$ by environmental factors, $20 \%$ by genetic predisposition and $10 \%$ by the medical care system. From this breakdown, it is obvious that $80 \%$ of our health status is determined by factors other than those we have at birth.

\section{BACKGROUND}

The title of my paper, "Social determinants of health and disease", is very broad and seen from a medical point of view appears to support a cause or a determinant behind the disease giving a certain number of symptoms. Symptoms are seen to be caused by a disease, and for most diseases we try to find causative agents of some kind. Biomedical thinking at all levels is pervaded by cause and effect or analytical reasoning. Clinicians often express this idea by saying that they must treat the disease rather than the symptoms, and in that way they imply that the disease is the cause of the symptoms (Wulff et al., 1990: 62). Medical scientists who are engaged in laboratory research usually look for the cause inside the humam body, and the epidemiologists seek the causes in the environment. Here follows an example of the link between social causes, factors and/or determinants resulting in a certain disease, just to show the complexity.

Figure 1 shows that the causes resulting in a certain disease can be categorized according to the Health Field concept of Lalonde and Blum (social/environmental, lifestyle, genetic and health care). A host of factors interact in a complex causal web, but our knowledge of the underlying mechanisms is still limited, and the effect of medical treatment will depend on the location of these factors in the causal network.

We also know that any assessment of the effect of a therapeutic intervention must take into account the healing power of nature, the self-defense and recuperating power of the body, the mechanisms of homeostasis, and the importance of vicious circles. The risk factors underlying a certain symptom also have to be seen in connection with the genetic constitution of the individual.

FIGURE 1. The Casual Complex in a Case of Cirrhosis of the Liver

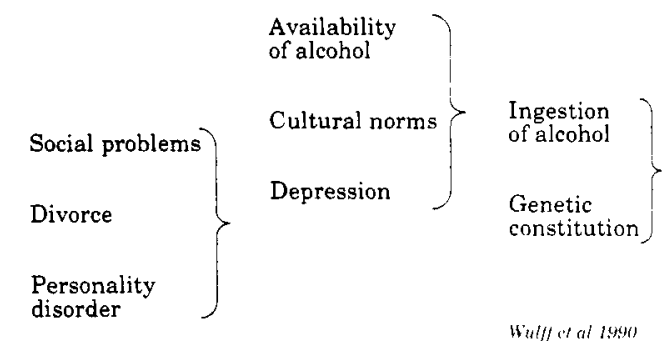


As we can see from the above example, the interpretation of the relationship between environment and health is, as we all know, extremely complex. Nethertheless, I will "broaden the context" and go beyond the medical paradigm.

\section{CHOICE OF PERSPECTIVE}

In human ecology the interaction between human beings and their environment is studied. The subject is interdisciplinary in character, that is, the field of research, including methods, is taken from different disciplines and the research questions are broader and might be seen as more innovative than in the specialist disciplines. The reason for this is that a new interdisciplinary field is not limited or bound by traditional theories, methods and research fields.

My own research has mainly been within the field of health issues. My fieldwork in the Peruvian part of Amazonas during the 80s resulted in a dissertation, Environmental Changes and Human Health, a Study of the Shipibo-Conibo in Eastern Peru. I have also been in Mexico, studying the traditional medical system among the Maya population in Yucatán. I am especially interested in their interpretation and treatments of illnesses. I also have some experience with a local health project in Sweden, Koster Health. I will start with a discussion based on my empirical experience with two case studies, from Sweden and Peru.

\section{CASE STUDY 1: THE KOSTER HEALTH PROJECT}

The Koster Islands are the westernmost populated islands of Sweden. They are located in the Skagerak, 10 kilometers west of the Swedish mainland and close to the Norwegian border. Koster consists of two larger islands, North Koster and South Koster, separated by a narrow strait.

Koster has at present about 350 permanent inhabitants with a very low geographical mobility. This facilitates longitudinal studies
FIGURE 2. The Koster Health Project

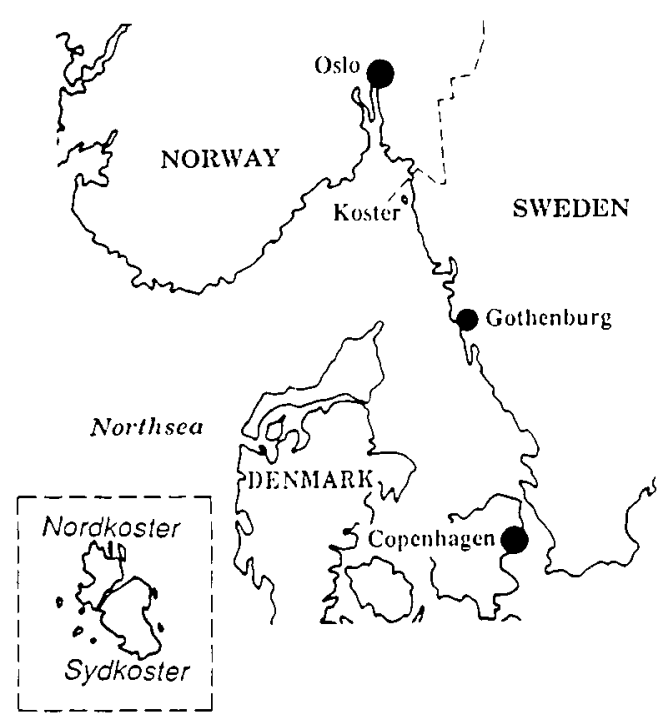

on the interaction between human individuals and their environment. Three generations of the same families may be followed up on Koster. Population growth is the same as in the rest of Sweden and intermarriages do not occur. Even the young people want to remain on the islands. The question is - what means of subsistence exists on the islands in today's changing living environment?

There are a number of environmental threats to a viable archipelago and to the genuine cultural tradition it represents.

The sea around Koster Islands is slowly dying. Seaborne pollutants are transported to the Koster archipelago by sea currents from densely populated countries in westem Europe. Norwegian paper pulp and aluminiun industries contribute to the ongoing changes in the regional environment. Possibly related, poisonous flowering algae have already had 
disastrous effects on the quantity and quality of fish. Even the large seal colony in the area has been drastically reduced - partly due to virus infections after a lowering of their immune defense, possibly in association with environmental changes.

There has been a tendency for lobsters to change shells too often - probably due to the increase of certain petroleum products in the sea which are similar to the hormone regulating the life cycle of the lobster. A lobster which changes shells too often is an easy prey for its enemies.

Airborne and rainborne pollutants are brought to the islands from across the sea with the prevailing westerly winds. Oil-mixed soot is brought from Great Britain. The rain that falls on Koster may have an acidity of approximately $\mathrm{pH} 3.0$. It contains high amounts of nitrate, aluminium and copper. The acid rain and the windborne salt from the sea due to changes in climate cause environmental damage, impoverish the earth and threaten the limited ground water of the islands. As Koster has no motor traffic or polluting industries, the area is well suited for longitudinal studies on ongoing variations of the background environment.

The islanders themselves are also involved in the deterioration of their immediate environment. The sewage systems of the households are partly defective and definitively underdimensioned for the tenfold increase in the number of people living on the islands during the summer, that is, during June, July and August.

The limited amount of ground water and, hence, the drinking water is one of the more serious threats for the islanders.

The changes in the immediate environment may affect the islanders occupationally, psychologically, and physically. Such individuals" reactions to environmental stress have been monitored annually since 1987 , in a multidisciplinary research project called

\section{Koster Health.}

This multidisciplinary development project has a human ecological research perspective: it studies the interactions between Man and his/her total environment. The relations between society and its natural environment are of fundamental importance. The scientists participating represent different disciplines, such as medicine, odontology, human ecology, domestic ecology, psychology, history, botany, marine biology, hydrogeology, physics and inorganic chemistry.

The project period is expected to last for a minimum of 15 years. Koster Health belongs to the UNESCO/Man and the Biosphere (MAB)-Insular Programme. It has also been adopted by WHO/Euro (Environment and Health) as a model for comparative studies on the interaction between environmental changes and human health.

\section{Aims of the Koster Project}

The project is mainly concerned with general medical and oral medical aspects. The health of 200 adult islanders is monitored annually by means of comprehensive interviews and comparatively simple clinical investigations. More attention is paid to the individual's subjective feelings of illness than to his objectively recognizable diseases. Each proband is his own control over the years. Koster Health is not a population study.

The main purposes of the project are:

- To record what is seen as optimal health by the individual, living in an area subjected to environmental stress;

- To find out what is the minimum level of medical and odontological interventions necessary in order to maintain the wellbeing of the individual - in spite of his/her possible diseases;

- To assist the islanders in the recognition and elimination of existing health traps and in taking on an increased responsibility for the supervision of his/her own health.

\section{Methods}

Approximately one and a half hours per proband per year have been allocated for interviews, clinical examinations and macrophotography of oral tissues and possible skin lesions. One physician and one dentist 
collaborate in the annual follow-up of each islander.

The photographic documentation (colour slides) facilitates objective analyses of the actual clinical status of each individual and render retrospective health comparisons possible. They also form a most valuable tool for motivating the individual to be aware of his/her own health variations and, therefore, to be open to possible health promoting interventions.

All interviews, clinical examinations and evaluations of the photographic material are based on a series of standardized protocols, approved by UNESCO/MAB and WHO/EURO for comparative studies on human responses to environmental changes. Data from social-psychological, nutritional, general medical, oral medical and environmental protocols are stored in a database for statistical analyses.

The social-psychological protocol concerns matters of schooling, employment, working environment, leisure activities, social network etc.

The nutritional protocol includes detailed information on the daily, weekly and monthly consumption of a listed number of products. The individual's intake of sea food and different kinds of liquid is given special attention.

The general medical protocol contains a survey of the health and possible causes of death of different members of the proband's family. The anamnestic part of the protocol comprises diseases diagnosed earlier during the islander's life time. It also includes a comprehensive review of subjective symptoms of illness, recognized by the proband during the two weeks before the interview, as well as a record of, among others, the possible smoking and drinking habits of the individual. The clinical checkups of the proband involve a series of body measurements and blood pressure tests. The main objective of the comparatively simple, non-invasive examinations is to disclose possible symptoms of cardiovascular, gastrointestinal, respiratory and skin disorders.

The anamnestic part of the oral medical protocol concerns previously diagnosed and present oral diseases and illnesses. The oral health status of the proband is evaluated on the basis of comparative analyses of the series of close-up photographs (15-20 slides) taken each year. Possible tissue changes from one year to another are recorded. The photographs are not used for diagnosis of diseases. Oral health is dependent on many factors outside the mouth. It is important to emphase that the arrow in Figure 3 is only pointing in one direction. That means that the factors in the circle are influencing each other in a central direction.

\section{FIGURE 3. The Koster Health Project}

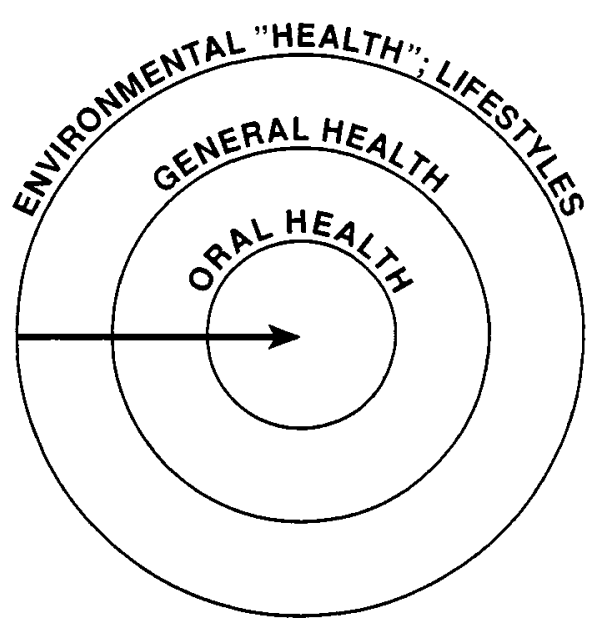

The technological scientists on the project are responsible for the physical and chemical data on the environmental protocol. Airborne, rainborne and seaborne pollutants, indoor radon levels, radon levels of the ground water and variations in the quality of the drinking water in the different households are analysed every year. Botanists perform macrophotographic follow-ups of 60 species of lichens growing on the rocks exposed to the wind from the open sea. The accumulation of heavy metals in the root systems of water plants in small brooks and ditches is being analysed.

\section{Preliminary Findings}

Brief reports on the progress of the studies are completed each year. More comprehensive scientific reports will be presented in international journals in the next few years, 
but some papers have already been published (Follér \& Heyden 1990; Heyden 1989; Heyden \& Eliasson 1990; Heyden 1990; Heyden 1991).

\section{Environmental Health}

The acid and windborne salt already mentioned seem to impoverish the earth, induce plant life changes, and threaten the quality of the limited volume of ground water of the islands.

High amounts of copper, zinc, uranium and cadmium have been disclosed in the roots of water plants. Some of the pollutants seem to originate from the sewage systems of the households.

In periods with high consumption of drinking water the impurities of the sea water and the brook (recipient) water may leak into the ground water and the drinking water wells. Preliminary studies have demonstrated that the regionally high metal and bacterial content of the drinking water may be markedly reduced, at least temporarily, by means of comparably simple hygienic improvements in the wells.

\section{Human Health}

The deterioration of the marine environment affects the islanders in individual ways. The population's main source of income is jeopardized, which might give rise to, among others, mental strain and adoption of healththreatening lifestyles.

An increased awareness of ongoing changes in the islanders' immediate environment and an increased readiness to assist personally in practical interventions to reduce the local environment hazards (with assistance from the project technologists) seem to have beneficial psychological and somatic effects on the probands. For example, both the process and the result of cleaning a drinking water well may markedly reduce the number of subjective symptoms of illness of the actor.

The clinical photographs have proved to be a most important medium for healthpromoting discussions and interventions.
The first five years of the Koster Health project have proved that the oral soft tissues are important mirror images of the general health of the human individual. Even though they may demonstrate changes in the health status from one year to another, they should not be used for the diagnosis of extraoral diseases.

The holistic approach of the Koster Health project has been appreciated by both the probands and the participating scientists. Each human individual is biologically unique. There are no control groups - longitudinal, intraindividual comparisons of health changes seem to be more valid than cross-sectional, interindividual ones. There are many realities in the life of a human being that cannot be explored or explained by means of traditional, scientific tools. Koster Health aims at identifying some of these realities by means of partly unconventional methods. Long-term follow-ups of the continuous health-promoting interventions may compensate for some of the scientific shortcomings.

\section{CASE STUDY 2: AMETRA - A LOCAL HEALTH PROJECT}

This study will present some general characteristics of the adaptation which the Shipibo-Conibo have made to their environment, with particular reference to their health situation. Another purpose is to show how the process of socio-cultural transformations going on among the indigenous population and the environmental changes taking place affect health. Finally, some possible answers which the ethnic groups have elaborated to deal with these problems will be discussed. The ShipiboConibo are an ethno-linguistic group living along the Ucayali river in the central Amazonian jungle area (Figure 4). From an ecological point of view, the territory belongs to the tropical rain forest with its abundance of plant and animal species. The diversity of this ecosystem presents both opportunities and constraints for the people. The ShipiboConibo number 25,000 , distributed in 110-120 villages along the river banks or lakes. 
FIGURE 4. Ametra: Map of the ShipiboConibo Living Area

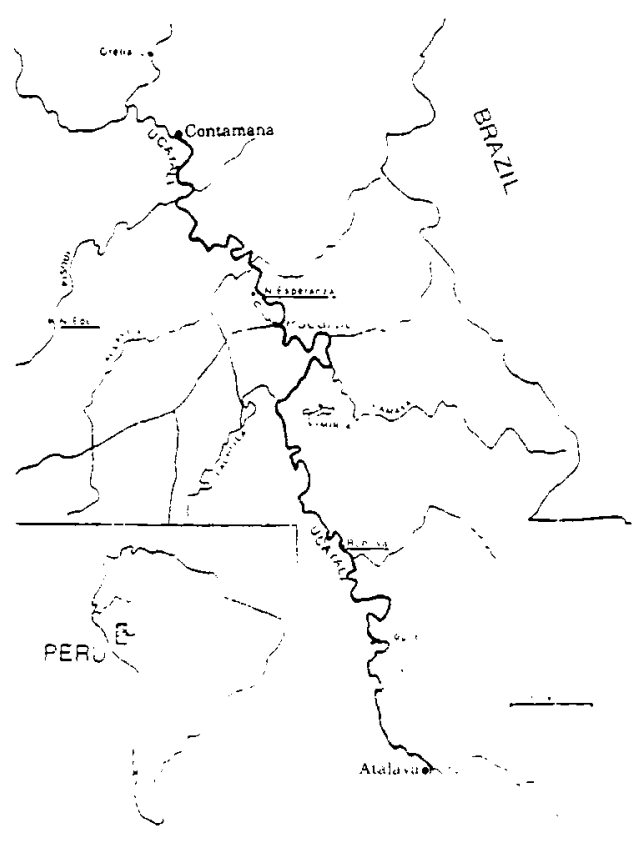

Indigenous Amazonian groups share some characteristics of the particular relation with the environment that are closely connected with their health situation:

- The periodical moving of the families every 10 to 15 years.

- Low population density mainly based on traditional fertility control methods and a high infant mortality.

Both these characteristics ensure that animal protein resources from game and fish are not overexploited.

- The relative isolation, with limited communication between the indigenous groups, has also had an important effect on the health situation.

- An emphasis on personal hygiene through daily bathing in the rivers.

- The painting of teeth with plant preparations to avoid tooth decay and the use of natural tooth sticks.
The characteristics of traditional living can today be translated in terms of preventive medicine and a complex totality of knowledge, myths and practices which confirm curative systems. The indigenous groups of the Amazon have been submitted to a very intense and continual process of change. This process has resulted in the definite incorporation of the ethnic groups into the national society and culture.

\section{Health Deterioration Due to Environmental Changes}

The alarming progress of epidemic diseases introduced from Western society, since the 16 th century such as measles, whooping cough, and small-pox, among others, has significantly reduced the indigenous populations. Syphillis, tuberculosis and leprosy are also contagious diseases that have been introduced. The cholera epidemic in the Ucayali basin in 1991 is a recent tragic example of suffering and death among the Shipibo-Conibo.

Nutritional impoverishment and changes in traditional house-building are other changes taking place that affect the health situation.

A well-functioning governmental health service is lacking in Peru as a consequence of the current economic and social crises.

\section{Some Solutions to the Health Problems}

The indigenous peoples are finding their own solutions, both new and original, to their health problems. For example, an association of people suffering from leishmaniasis has been organized among the Aymara and Quechua in the Puno area of southern Peru in order to get adequate treatment. On the northern coast of Peru in the Piura area, the indigenous people have organized a health programme of their own to diminish the high mortality among women of childbearing age (Cardenas et al., 1991).

The Shipibo-Conibo experience is the organization AMETRA - which means the application of traditional medicine.

Through courses in the villages, written materials and programmes on the indigenous 
radio channels, AMETRA is making people aware of the strength of their own traditional medicine. At the same time, it is making them aware of the necessity to protect lands and lakes from intruders or non-compatible, foreign techniques in order to survive. The Shipibo-Conibo are able to reinforce their ethnic identity in this way.

The AMETRA experience in Ucayaly has become known and is applied by other ethnic groups in Peru.

\section{FIGURE 5. Ametra}

\section{AIMS OF AMETRA}

\section{- Acceptance of traditional medicine \\ - Extensive use of local resources \\ - Correct use of vegetable and comercial drugs \\ - Conservation of floral and faunal resources}

\section{A HUMAM ECOLOGICAL PERSPECTIVE}

With these case studies as an empirical background, I want to discuss the interaction between human health and the environment. I will also make some general references to the case studies. It is not only a question of the risk factors causing diseases but also, as mentioned earlier, of what factors are important to the maintenance of the health of the individual. My principal inspiration for what I will call the human ecological perspective has come from health researchers such as Aaron Antonovsky, René Dubos and Henrik Blum. Even if none of them mentions the concept of human ecology, their underlying ecological and interdisciplinary approaches have given me a lot of food for thought.

Dubos, a well known microbioligist, develops an ecological view which is global - a way of looking at the world - in its approach. The capacity of human beings to adapt to changes in the environment is put in focus. The human ability to use this capacity is potentially great, and this is central to one's health. In his book, written in the 1980 s, Dubos states that even if today's mechanized development is a threat to human adaptation, he is still optimistic about our possibilities for solving environmental problems. The danger for us is to lose our "humanness" and become dehumanized by the conditions of life. We have to keep still and reflect over how to control and manage our local environment. Adaptation and adaptability are key concepts in Dubos' discussion (1968, 1972, 1983).

Antonovsky (1981, 1991), a medical sociologist, takes as his starting point the functions or causes of health - salutogenes. His focus is primarily on health and not on disease, in contrast to the practioners of biomedicine. His question is, "How is it possible that so many individuals exposed to the strains from life remain healthy, grow up and develop as human beings?". His basic thought is that life is like a fast-flowing river with dangers and pollutants. It is not always possible to avoid the dangers and pollutants. The question of how to make the river less dangerous is, however, subordinate to the more central question, how to manage to swim. This approach is dynamic and, as I see it, complementary to the biomedical causeand-effect paradigm regarding the relation between health and environment. The question to put forward is thus, "How is it possible to measure the ability to swim, and what scientific tools do we have?" One methodological tool Antonovsky uses is the concept of "sense of coherence", or what he calls "a global capacity of orientation". I interpret this as an attempt to find a connection between the individual's internal and external environments.

Humans beings interact both among themselves at different social and cultural levels and with the biotic and abiotic environment. The influences of the environment on human health can be both positive and negative. Instead of just examining risk factors - which is the most prevalent method in environmental and social medicine and epidemiology resulting in a certain process of disease, 
FIGURE 6. Organization of AMETRA

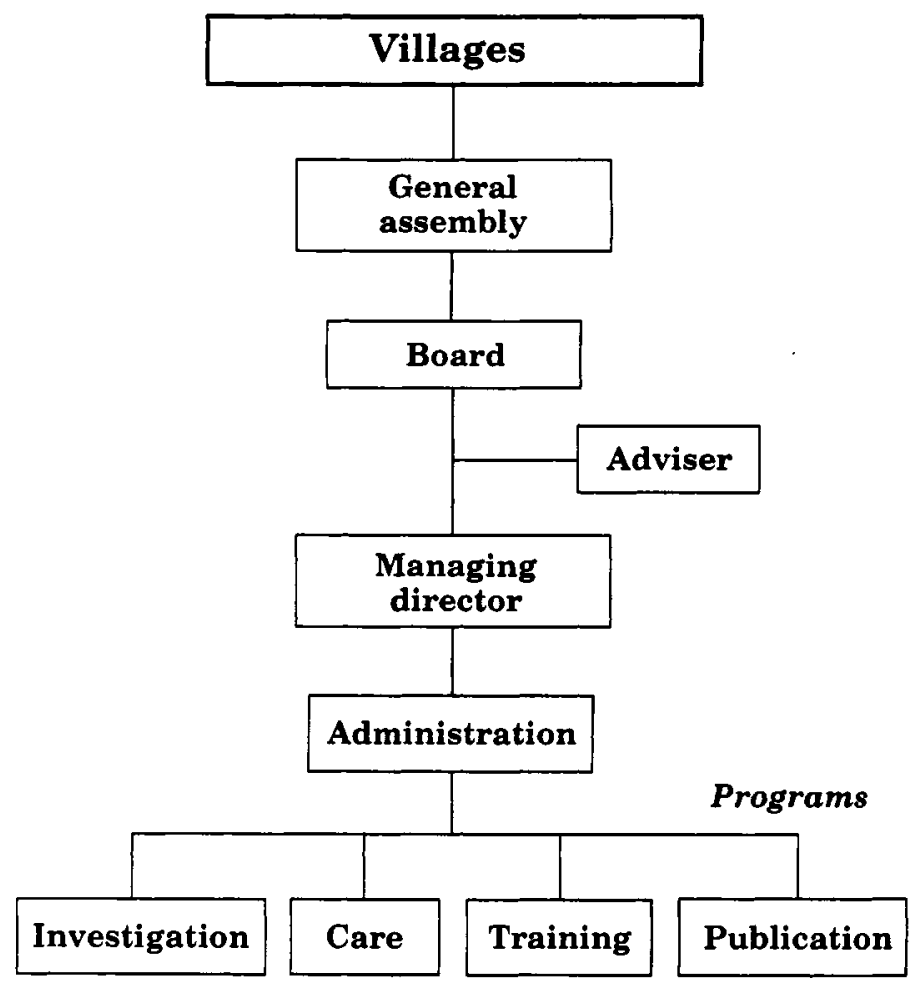

Antonovsky looks at health (ease) and ill health (disease) as antipoles in a continuum and asks what determinants act as buffers and in what sense they directly contribute to health and disease. The concept "sense of coherence" is one important determinant for humam well-being. The concept has three components which he finds crucial for a healthy individual:

- Meaningfulness (that is, to give significance to symptoms that are defined as illness and not connected with disease in the social and cultural context).

- Comprehensibility.

- Manageability.

My own opinion is that the human ecological perspective regarding healthpromoting work at the micro level is in the force field between how to "handle" the individual health problems and how to contribute to a better social and natural environment. The strategies in the above examples from the Koster Health project and AMETRA are inspired by such thoughts. I want to go beyond the dualism of realism and empiricism. I therefore question a causal relationship between social determinants or environmental determinants as sufficient in a human ecological health research project. A balanced health study, as I see it, will take into account the mobilizing and knowledgegenerating processes. Henrik Blum uses a "well-being paradigm", which I believe has many similarities to Antonovsky's "sense of coherence". Blum uses the components, reciprocal action (between the individual and his/her total environment), mutual dependence, and variability.

In his paradigm, health is seen as a normative concept. It has a value, and it is feasible for the individual to promote and influence his/her health situation. The individual is an active subject for his/her own health. Health is presented as an aim, 
something to fight for, a liberation of the human potential. This concept of health is, as I see it, much more qualified and analytical than the definition from WHO, which just points out freedom from symptoms (Lindén 1991: 54).

There is a growing interest in external influences, determinants, on human health, that is, from the social and natural world, in today's societies. The environmental deterioration taking place at a global, regional and local level is one reason for this interest.

I have mainly discussed the environmental factors and the lifestyle and ways of life. Most health scientists will probably agree that these are the main influences on human health. Our genetic constitution does play an important role and the individual differences are great. Medical statistics forming the basis of governmental health recommendations are not interesting when they are translated to the individual level. I do believe in the importance of a strong national health policy based on available scientific knowledge such as: a) production and provision of tobacco and alcohol; b) substances abuse; c) nutrition policy (less fat, more fibre); d) food availability/accessibility; e) environmental factors; $f$ ) health care system; but, at the same time, every human being has to find his/her own limits and establish his/her own way of living. Every human being has his/her own health profile.

Illich (1978) and Blum (1983), among others, have stated that an improvement of the health sector will not necessarily become causally linked to a future improvement of the health status of the population. From the situation in industrialised countries, it may be concluded that the impact of the health care system as such on the general health status of a given population is limited, "a modest contribution" as Blum puts it (Blum 1983: 34).

\section{RESUMO}

FOLLÉR, M. Determinantes Sociais de Saúde e Doença: O Papel de Pequenos Projetos em Saúde Ilustrado pelos Projetos Koster na Suécia e Ametra no Peru. Cad. Saúde Públ., Rio de Janeiro, 8 (3): 229-239, jul/set, 1992.

Este artigo revê e avalia dois projetos de saúde - o Koster Health Project realizado nas ilhas Koster, Suécia, e o Ametra Project, realizado entre os indígenas Shipibo-Conibo, Peru. Ambos enfocam, principalmente, os determinantes de saúde, ao invés da doença. Os projetos também privilegiam em suas abordagens os sentimentos subjetivos individuais sobre a doença, ao invés de doenças "objetivamente" reconhecidas pela biomedicina.

"Mobilização" e "responsabilidade" pela saúde do próprio indivíduo são conceitos centrais em ambos os projetos. $O$ artigo busca na ecologia humana o suporte teórico para analisar a interação entre saúde humana $e$ mudanças ambientais. A autora enfatiza a importância da pesquisa interdisciplinar na avaliação do papel exercido pelos fatores naturais e sociais sobre os seres humanos e a saúde. A abordagem da ecologia humana é vista como complementar à pesquisa biomédica sendo, saúde e doença, concebidas como dois pontos em um continuum. A autora argumenta que em uma sociedade pluralista deve-se lutar no sentido de se avançar rumo ao polo da saúde.

Palavras-Chave: Ecologia Humana; Saúde; Mobilização Social; Ilhas Koster; Índios Shipibo-Conibo

\section{REFERENCES}

ANTONOVSKY, A., 1981. Health, Stress and Coping, London: Jossey-Bass Publishers. 1991. Hälsans mysterium (Unraveling the Mystery of Health, original title). Köpong: Natur och Kultur.

CÁRDENAS, T. C.; FOLLÉR, M. \& HANSSON, A., 1991. Ecological Changes and Health Systems in Eastem Peru. Journal of Human Ecology, 2: 29-38. 
DUBOS, R., 1968. So Human and Animal. New York: Charles Scribner's Sons. 1972. Man Adapting. New Heaven: Yale University Press. 1983. Hyllnigar till Livet (Celebrations of Life, original title). Stockholm: Brombergs Bokförlag.

BLUM, H. L., 1981. Planning for Health. Generics for the Eighties. New York: Human Sciences Press.

1983. Expanding Health Care Horizons. From a General Systems Concept of Health to a National Health Policy. Oakland: Third Party Publishing Company.

FOLLER, M., 1990. Environmental Changes and Human Health, A Study of the Shipibo-Conibo in Eastern Peru. Humanekologiska skrifter 8, Göteborgs: Göteborgs universitet.

FOLLER, M. \& HEYDEN, G., 1990. A New Approach to Interdisciplinary Health Studies: The Koster Health Project. Nutrition \& Health, 7: 3542.

HANSSON, A. G. \& ARÉVALO, V., 1985. Algunos Aspectos de Medicina Tradicional en Ucayali (Proyecto AMETRA). Lima: Instituto Indigenista Perua.

HEYDEN, G., 1989. The Koster Health Project: An Interdisciplinary Development project with a Focus on Human Ecology. Human Ecology Bulletin, 6: 16-18.
, 1990. Critical issues of Ageing: The Dentist as a Supervisor of the General Health of the Elderly. International Dental Journal, 40: 63-65.

1991. The Koster Islands and the Koster Health Project, Territories et Sociétés Insulaires, Colloque International (UNESCO), Brest, France. Collection Recherches Environnement, 36: 81-84.

HEYDEN, G. \& ELIASSON, L., 1990. Clinical Macrophotography for Oral Health Monitoring Purposes. Methods and Results from a Comparative Study. Sweden Dental Journal, 14: 1-7.

ILLICH, I., 1978. Medical Nemesis. New York: Aldus New York.

JOHANNISSON, K., 1990. Sjukdom som kulturell kostruktion. Tvärsnitt, 1: 26-33.

LALONDE, M., 1974. A New Perspective on the Health of Canadians. Ottawa: Office of the Canadian Minister of National Health and Welfare.

LINDEN, K., 1991. Kvinnor, Hälsa, Handling (Women, Health, Action). Göteborg: University of Göteborg.

WULFF, H. R.; PEDERSEN, S. A. \& ROSENBERG, R, 1990. Philosophy of Medicine, an Introduction. Oxford: Blackwell Scientific Publications. 